\title{
Biochemical and genetic diversity of carbohydrate-fermenting and obligate amino acid-fermenting hyper-ammonia-producing bacteria from Nellore steers fed tropical forages and supplemented with casein
}

\author{
Cláudia Braga Pereira Bento , Analice Cláudia de Azevedo', Edenio Detmann² and Hilário Cuquetto Mantovani ${ }^{{ }^{*}}$
}

\begin{abstract}
Background: Dietary protein plays a major role in ruminant nutrition, and protein supplementation is a widespread practice among farmers in the tropics. Ruminal bacteria are the main agents of dietary protein and amino acid degradation, yet few studies have focused on the isolation and characterization of hyper-ammonia-producing bacteria in animals fed tropical diets or supplemented with rumen-degradable proteins. This work investigated the bacterial community diversity of the rumen of Nellore steers fed tropical forages, with or without casein supplementation. We also isolated and characterized ruminal bacteria showing high levels of ammonia production.

Results: Polymerase chain reaction-denaturing gradient gel electrophoresis analysis indicated no differences in the ruminal bacterial community composition between the control and supplemented animals. Amino acidfermenting bacteria $(n=250)$ were isolated from crossbred Nellore steers fed Tifton 85 (Cynodon sp.) using trypticase as the sole carbon and organic nitrogen source in the enrichment and isolation media. The deamination rates in isolates obtained from steers supplemented with casein showed a higher incidence of deamination rates $>350 \mathrm{nmol}$ $\mathrm{NH}_{3}$ mg protein ${ }^{-1} \mathrm{~min}^{-1}(P<0.05)$, whereas isolates obtained from steers without supplementation showed deamination rates $<200 \mathrm{nmol} \mathrm{NH} 3 \mathrm{mg}$ protein ${ }^{-1} \mathrm{~min}^{-1}$. Although most isolates (84\%) could ferment carbohydrates, none could hydrolyze proteins or use urea to sustain growth. All isolates were sensitive to lasalocid and monensin $\left(1 \mu \mathrm{mol} \mathrm{I}^{-1}\right)$, and similarity analysis of the 165 rRNA sequences indicated a predominance of bacteria from the order Clostridiales, with variable homology (73-99\%) to known bacterial species.

Conclusions: These results expand what is known about the biochemical and genetic diversity of hyper-ammoniaproducing bacteria, and emphasize the role of carbohydrate-fermenting bacteria in ammonia production in the rumen.

Keywords: Deamination, Clostridiales, ionophores, dietary protein, PCR-DGGE
\end{abstract}

\footnotetext{
* Correspondence: hcm6@ufv.br

${ }^{1}$ Departamento de Microbiologia, Universidade Federal de Viçosa, Viçosa, MG 36570-000, Brazil

Full list of author information is available at the end of the article
} 


\section{Background}

In tropical regions, the availability of forage and the quantity and quality of protein available to ruminants varies depending on the season. Brazil, being classed as a tropical region, has two distinct seasons in terms of the availability of feedstuffs for ruminants: the dry season (April-September), and the rainy season (OctoberMarch) [1,2]. In the dry season, forages have a high insoluble fiber and lignin content; however, the crude protein content is usually $<7 \%$, which is considered limiting for the adequate function of ruminal microorganisms [1]. During the rainy season, forages show adequate levels of crude protein, but microbial protein synthesis is limited because of the high degradability of the dietary protein [2,3]. Protein supplementation is therefore a widespread practice in Brazil to provide a more balanced diet $[4,5]$. In the dry season, rumen-degradable protein (RDP) is provided to animals, whereas in the rainy season, rumen-undegradable protein is added to ruminant rations $[4,6]$.

Dietary protein in the rumen is degraded by the coordinated action of proteases, peptidases, and deaminases, producing peptides, amino acids, and ammonia, respectively [7]. Most of the ammonia produced is utilized by ruminal bacteria as a source of nitrogen. However, the catabolism of carbohydrates can occur faster than the incorporation of ammonia by rumen microorganisms. Ammonia accumulated in the rumen can be absorbed through the rumen wall, and is then converted to urea in the liver and excreted in the urine [7]. Recycling of urea in the saliva can help to balance the need for nitrogen in the rumen, and previous work indicated that 10 $40 \%$ of ruminal urea requirements could be supplied through urea secreted in saliva [8].

Previous reports have confirmed the role of several rumen bacteria in dietary protein deamination [9-16]. Some of these bacteria can also ferment carbohydrates in the rumen (e.g. Butyrivibrio fibrisolvens, Prevotella ruminicola, Eubacterium ruminantium). However, these carbohydrate-fermenting species cannot fully explain the deamination rates of mixed ruminal bacterial cultures $[14,15,17]$. Within the last 25 years, several Gram-positive and monensin-sensitive bacteria with high specific activity for ammonia production have been isolated from ruminants [10-16]. These hyper-ammonia-producing bacteria (HAB) were initially characterized as obligate amino-acid fermenters, and were found in small numbers in the rumen using molecular probes [18].

The physiological and genetic diversity of $\mathrm{HAB}$ was further explored by several different groups. McSweeney et al. [19] isolated a group of bacteria that could grow rapidly on peptides and amino acids, and had proteolytic activity, from the rumen fluid of sheep and goats fed tannin-rich diets based on Calliandra calothyrsus.
Although these bacteria were reported as HABs, the level of ammonia and biomass produced in the absence of carbohydrates was often low. The idea that biochemical diversity within the $\mathrm{HAB}$ group was greater than initially thought was emphasized by the presence of significant populations of HABs in pasture-grazed New Zealand ruminants [12]. This idea was further supported by the work of Russell [14], who demonstrated that Fusobacterium necrophorum, a Gram-negative, nonmotile, and rodshaped bacterium, degraded lysine with a very high rate of deamination $\left(2,400 \mathrm{nmol} \mathrm{NH}_{3} \mathrm{mg}\right.$ protein $\left.{ }^{-1} \min ^{-1}\right)$. F. necrophorum was characterized as a carbohydratefermenting $\mathrm{HAB}$ that could produce acetic acid, butyric acid, and ammonia from the fermentation of lysine. Further work has indicated that HABs are also involved in protein metabolism in other mammals, and could play a major role in human health $[20,21]$.

However, studies focusing on the isolation, characterization, and quantification of HAB in animals fed tropical diets or supplemented with RDP are lacking. The utilization of dietary protein is a major factor limiting productivity in the tropics, and protein is the most expensive component of cattle diets. Thus, understanding the role of ruminal bacteria in dietary protein metabolism is essential for developing strategies to improve the efficiency of nitrogen retention in the animal, and to lower the costs of livestock production in these countries.

This work aimed to: 1) determine if there were differences in ruminal bacterial community composition between crossbred Nellore steers fed tropical forages, with or without casein supplementation; 2) isolate ruminal bacteria involved in amino acid and peptide metabolism from the rumen of steers, with or without RDP; 3) phenotypically and biochemically characterize isolates with high specific activity for ammonia production; and 4) determine the phylogenetic relationship of these HABs.

\section{Results}

In this study, we used polymerase chain reactiondenaturing gradient gel electrophoresis (PCR-DGGE) to evaluate the bacterial community composition of different animals consuming tropical forages, with or without casein supplementation infused directly into the rumen of the fistulated animals. Amplification of the 16S rRNA V3 region revealed a range of 28-35 amplicons (average of 32 amplicons) that showed low similarity between treatments (with and without casein infusion into the rumen) and between the animals used in this study. This result indicated that each animal had a different microbial community structure, and the only parameter that grouped samples together was the time of sampling (Figure 1), despite the fact that the ammonia concentration increased by $76 \%(P<0.05)$ in the rumen of the animals supplemented with casein. 


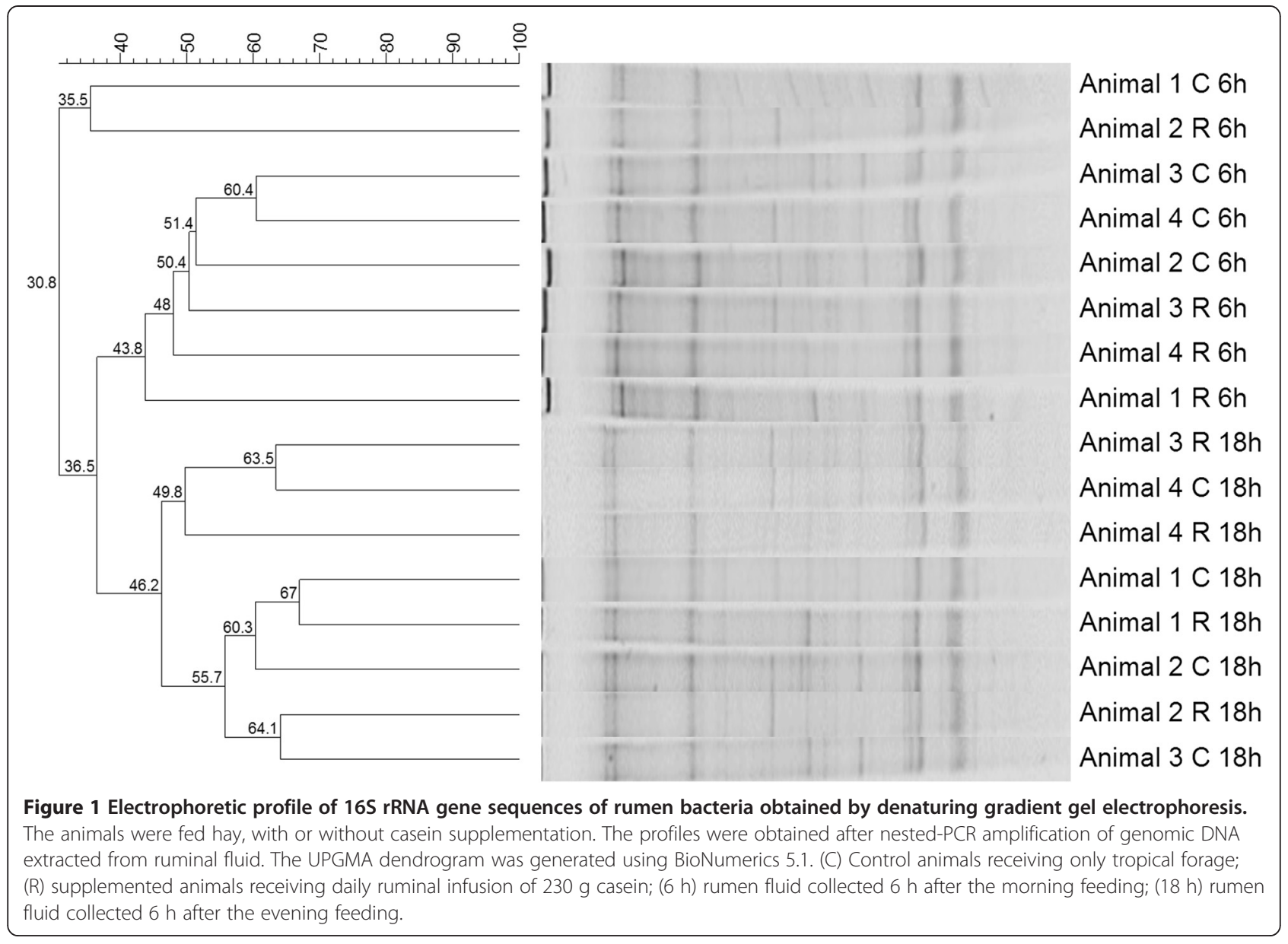

Because the ruminal infusion of RDP did not cause noticeable changes in the bacterial community composition, we hypothesized that the population of specialized bacteria involved in protein degradation and amino acid deamination was not being accessed by PCR-DGGE. To test this hypothesis, we decided to use culture-dependent techniques and enrichments in batch and continuous cultures to estimate the abundance, and to characterize the predominant phenotypes of amino acid-fermenting bacteria from crossbred Nellore steers fed tropical forages. A total of 250 individual isolates were isolated from fistulated animals, including 123 cultures obtained from control animals fed only basal forages, and 127 obtained from animals that received casein supplementation in the rumen.

The specific activity of deamination (SAD) and total ammonia production of each isolate was determined, and 30 isolates showing $\mathrm{SAD} \geq 100 \mathrm{nmol} \mathrm{NH}_{3} \mathrm{mg}$ protein $^{-1} \mathrm{~min}^{-1}$ and ammonia concentration $\geq 25 \mathrm{mmol} \mathrm{l}^{-1}$ after $24 \mathrm{~h}$ of growth were selected for further characterization. All experiments were performed using trypticase as the sole nitrogen source. Morphological analysis of the cultures by light microscopy indicated that the majority of the isolates were motile (60\%)
Gram-positive bacilli (the only exceptions were isolates C34 and R36, which were Gram-negative), and were able to form spores $(80 \%)$ (Table 1). When bacteria were grown in anaerobic mineral medium containing trypticase as the sole source of carbon and energy, the maximum optical density $(600 \mathrm{~nm})$ ranged from 0.406 (isolate R60) to 0.838 (isolate R23) (Table 1).

Mixed rumen microorganisms from steers supplemented with casein were significantly more likely to show deamination rates greater than $350 \mathrm{nmol} \mathrm{NH}_{3} \mathrm{mg}$ protein $^{-1} \min ^{-1}(P<0.05)$, while mixed cultures obtained from steers without supplementation showed SAD lower than $200 \mathrm{nmol} \mathrm{NH} \mathrm{NH}_{3} \mathrm{mg}$ protein ${ }^{-1} \min ^{-1}$ (Figure 2). Among the pure cultures, isolate R23 showed the highest SAD (608 $\mathrm{nmol} \mathrm{NH}_{3} \mathrm{mg}$ protein ${ }^{-1} \mathrm{~min}^{-1}$ ), while isolate R34 produced the highest total ammonia concentration in vitro $\left(44.2 \mathrm{mmol} \mathrm{l}^{-1}\right)$ (Table 1$)$. The average total concentration of ammonia produced by pure cultures after $24 \mathrm{~h}$ of incubation was $32.1 \pm 5.5 \mathrm{mmol}$ $\mathrm{I}^{-1}$ (Table 1). Isolates C116, R96, and R97 produced the lowest concentrations of ammonia, and were among the cultures showing reduced optical densities when grown in trypticase. 
Table 1 Phenotypic characteristics of hyper-ammonia-producing bacterial isolates* obtained from Nellore steers

\begin{tabular}{|c|c|c|c|c|c|c|c|c|}
\hline Isolate ID** & $\begin{array}{l}\text { Cell shape/gram } \\
\text { staining }\end{array}$ & Enrich. ${ }^{1}$ & Cultural characteristics & Mot. $^{2}$ & Spore & Maximum $O D^{3}$ & $\mathrm{SAD}^{4}$ & $\mathrm{NH}_{3}^{5}$ \\
\hline C11 & Rod-shaped. Gram + & 15 & White/small colony ${ }^{6}$ & + & - & $0.631 \pm 0.025$ & $114.85 \pm 3.14$ & $34.30 \pm 1.88$ \\
\hline C33 & Rod-shaped. Gram + & 15 & White/large colony ${ }^{8}$ & + & + & $0.820 \pm 0.091$ & $129.46 \pm 2.87$ & $37.25 \pm 3.67$ \\
\hline C34 & Rod-shaped. Gram - & 15 & Translucent/small colony & - & - & $0.776 \pm 0.052$ & $112.69 \pm 1.23$ & $34.44 \pm 1.15$ \\
\hline C37 & Rod-shaped. Gram + & 15 & White/small colony & + & + & $0.681 \pm 0.001$ & $101.25 \pm 4.57$ & $33.29 \pm 3.47$ \\
\hline C47 & Rod-shaped. Gram + & 1.5 & White/small colony & - & + & $0.575 \pm 0.037$ & $146.47 \pm 2.51$ & $34.87 \pm 0.46$ \\
\hline C48 & Rod-shaped. Gram + & 1.5 & White/small colony & + & + & $0.647 \pm 0.071$ & $129.48 \pm 2.85$ & $41.29 \pm 3.93$ \\
\hline C51 & Rod-shaped. Gram + & 1.5 & White/small colony & + & + & $0.637 \pm 0.016$ & $106.86 \pm 1.25$ & $36.21 \pm 0.88$ \\
\hline C54 & Rod-shaped. Gram + & 1.5 & White/medium colony ${ }^{7}$ & - & + & $0.562 \pm 0.041$ & $128.01 \pm 3.98$ & $28.35 \pm 2.01$ \\
\hline C89 & Rod-shaped. Gram + & 15 & Translucent/medium colony & - & + & $0.675 \pm 0.045$ & $203.27 \pm 5.76$ & $33.65 \pm 1.83$ \\
\hline C114 & Rod-shaped. Gram + & 1.5 & Translucent/small colony & + & + & $0.434 \pm 0.039$ & $278.25 \pm 4.65$ & $33.90 \pm 0.96$ \\
\hline C116 & Rod-shaped. Gram + & 15 & $\begin{array}{l}\text { Translucent border and } \\
\text { black center/medium colony }\end{array}$ & - & + & $0.332 \pm 0.015$ & $286.45 \pm 1.32$ & $25.15 \pm 5.21$ \\
\hline C117 & Rod-shaped. Gram + & 15 & $\begin{array}{l}\text { Translucent border and } \\
\text { black center/medium colony }\end{array}$ & + & + & $0.671 \pm 0.048$ & $186.98 \pm 2.03$ & $39.99 \pm 1.69$ \\
\hline C118 & Rod-shaped. Gram + & 15 & $\begin{array}{l}\text { Translucent border and black } \\
\text { center/medium colony }\end{array}$ & - & + & $0.609 \pm 0.092$ & $222.70 \pm 3.04$ & $34.15 \pm 0.25$ \\
\hline C122 & Rod-shaped. Gram + & 15 & Translucent/large colony & + & - & $0.647 \pm 0.045$ & $283.41 \pm 3.15$ & $35.09 \pm 1.98$ \\
\hline R15 & Rod-shaped. Gram + & 15 & Translucent/small colony & + & + & $0.601 \pm 0.022$ & $143.75 \pm 2.53$ & $39.02 \pm 2.01$ \\
\hline R21 & Rod-shaped. Gram + & 1.5 & Yellow/medium colony & + & - & $0.577 \pm 0.016$ & $469.23 \pm 6.76$ & $26.01 \pm 3.62$ \\
\hline R23 & Rod-shaped. Gram + & 1.5 & Translucent/medium colony & + & - & $0.838 \pm 0.093$ & $608.18 \pm 7.31$ & $30.88 \pm 6.25$ \\
\hline R34 & Rod-shaped. Gram + & 15 & Translucent/small colony & + & + & $0.742 \pm 0.056$ & $432.04 \pm 4.08$ & $44.17 \pm 4.82$ \\
\hline R36 & Rod-shaped. Gram - & 15 & White/medium colony & - & - & $0.561 \pm 0.037$ & $298.91 \pm 2.29$ & $33.33 \pm 1.19$ \\
\hline R40 & Rod-shaped. Gram + & 15 & White/large colony & + & + & $0.594 \pm 0.048$ & $180.92 \pm 2.97$ & $30.59 \pm 2.05$ \\
\hline R50 & Rod-shaped. Gram + & 1.5 & Translucent/medium colony & + & + & $0.660 \pm 0.008$ & $371.16 \pm 4.47$ & $38.01 \pm 0.87$ \\
\hline R51 & Rod-shaped. Gram + & 1.5 & Translucent/small colony & - & + & $0.662 \pm 0.089$ & $207.05 \pm 1.64$ & $26.55 \pm 3.44$ \\
\hline R60 & Rod-shaped. Gram + & 1.5 & White/large colony & - & + & $0.406 \pm 0.032$ & $475.22 \pm 8.91$ & $27.42 \pm 7.24$ \\
\hline R61 & Rod-shaped. Gram + & 1.5 & Translucent/medium colony & - & + & $0.435 \pm 0.015$ & $492.63 \pm 6.03$ & $27.42 \pm 7.31$ \\
\hline R63 & Rod-shaped. Gram + & 1.5 & Translucent/large colony & + & + & $0.415 \pm 0.076$ & $394.92 \pm 3.87$ & $25.47 \pm 9.97$ \\
\hline R90 & Rod-shaped. Gram + & 15 & Translucent/large colony & + & + & $0.612 \pm 0.077$ & $345.80 \pm 4.69$ & $27.31 \pm 3.22$ \\
\hline R91 & Rod-shaped. Gram + & 15 & Yellow/large colony & + & + & $0.535 \pm 0.015$ & $332.12 \pm 3.36$ & $32.50 \pm 5.18$ \\
\hline R96 & Rod-shaped. Gram + & 1.5 & Yellow/medium colony & - & + & $0.421 \pm 0.045$ & $381.73 \pm 4.05$ & $21.04 \pm 6.53$ \\
\hline R97 & Rod-shaped. Gram + & 1.5 & Yellow/medium colony & - & + & $0.573 \pm 0.106$ & $440.90 \pm 6.48$ & $21.55 \pm 6.25$ \\
\hline R107 & Rod-shaped. Gram + & 15 & White/large colony & + & + & $0.546 \pm 0.080$ & $197.60 \pm 3.54$ & $32.32 \pm 1.59$ \\
\hline
\end{tabular}

*The isolates were cultured in anaerobic mineral medium supplemented with $15 \mathrm{~g} \mathrm{I}^{-1}$ trypticase for up to $48 \mathrm{~h}$ at $39^{\circ} \mathrm{C}$.

${ }^{*} \mathrm{C}$, isolates obtained from animals not supplemented with casein; $\mathrm{R}$, isolates obtained from animals that received ruminal infusion of casein.

Symbols: (+) present; (-) absent.

${ }^{1}$ Concentration of trypticase $\left(\mathrm{g} \mathrm{I}^{-1}\right)$ used in enrichment cultures; ${ }^{2}$ Motility; ${ }^{3}$ Maximum optical density $(600 \mathrm{~nm}) ;{ }^{4}$ Specific activity of deamination (nmol NH 3 protein $\left.{ }^{-1} \mathrm{~min}^{-1}\right) ;{ }^{5}$ Ammonia $\left(\mathrm{mmol} \mathrm{I}^{-1}\right) ;{ }^{6}$ small colony $(\leq 0.5 \mathrm{~mm}){ }^{7}$ medium colony $(>0.5 \leq 1.0 \mathrm{~mm}) ;{ }^{8}$ large colony $(>1.0 \mathrm{~mm})$.

Values are provided as the mean \pm standard deviation of the mean.

Analysis of fermentation products by high-performance liquid chromatography (HPLC) demonstrated that most bacteria produced a variety of short-chain fatty acids from trypticase fermentation, with a predominance of acetic acid, propionic acid, butyric acid, isobutyric acid, isovaleric acid, and formic acid (Table 2). The total concentration of volatile fatty acids in individual cultures ranged from $12.3 \mathrm{mmol} \mathrm{l}^{-1}$ (isolate R97) to $79.9 \mathrm{mmol} \mathrm{l}^{-1}$ (isolate C48)
(Table 2). Three groups of bacteria, named high, medium, and low fermenters, were separated based on the concentration of fermentation products obtained from trypticase utilization. High fermenters produced, on average, 66.4 \pm $7.4 \mathrm{mmol} \mathrm{l}^{-1}$ of total organic acids from $15 \mathrm{~g} \mathrm{l}^{-1}$ trypticase (range: 53.7-79.9 $\mathrm{mmol} \mathrm{l}^{-1}$ ), while the average concentration of total organic acids in the cell-free supernatants of medium and low fermenter strains was $42.5 \pm 4.0$ (range: 


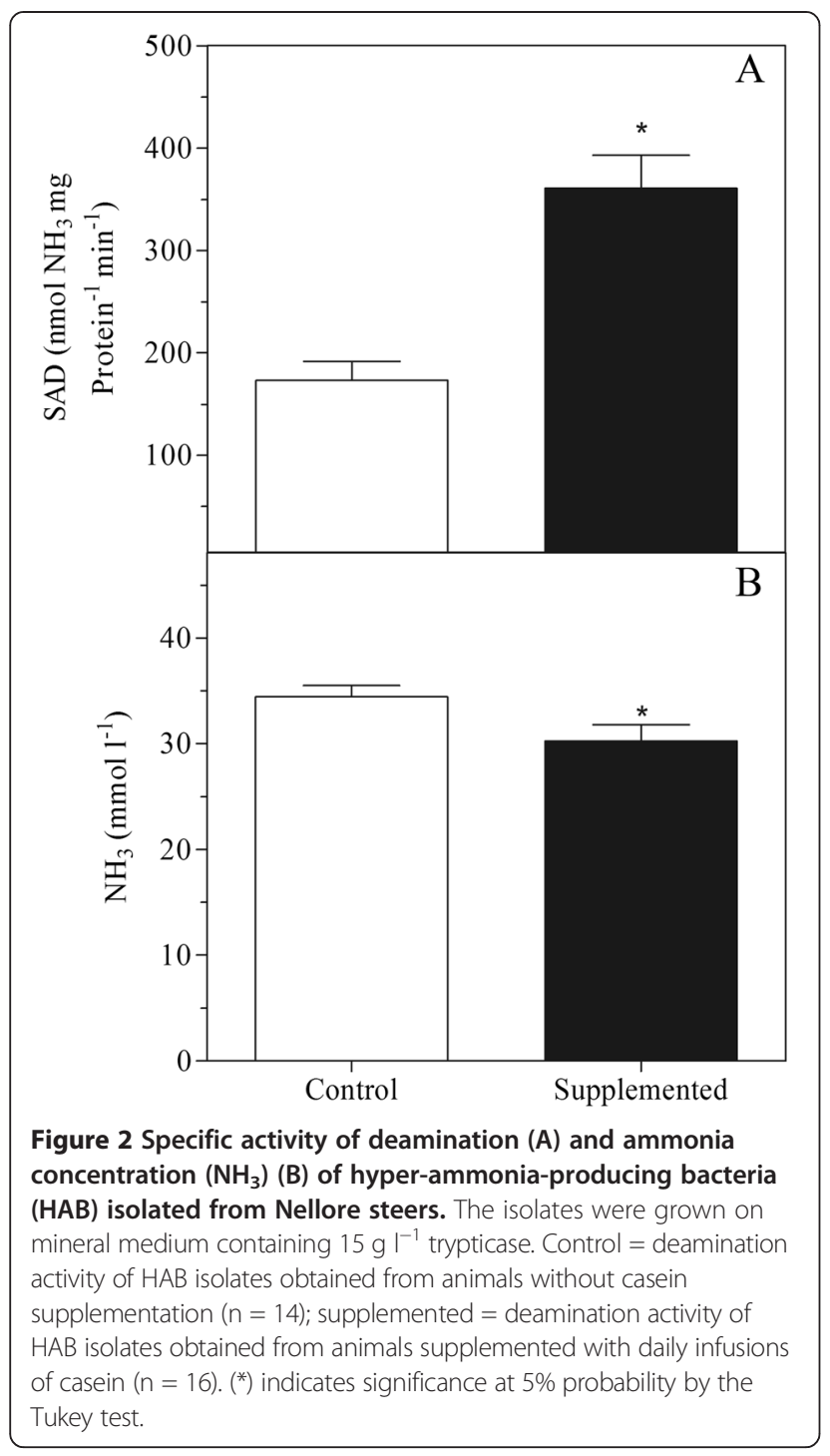

34.5-49.2 $\mathrm{mmol} \mathrm{l}^{-1}$ ) and $22.3 \pm 5.9 \mathrm{mmol}^{-1}$ (range: $12.2-$ $30.6 \mathrm{mmol} \mathrm{l}^{-1}$ ), respectively. The proportion of isovaleric acid in high fermenter strains was 2.6- and 4.7-fold greater than in medium and low fermenter strains, respectively, whereas these latter two groups of bacteria had, on average, greater proportions of isobutyric or formic acid in their fermentation end-products. However, the medium and low fermenter isolates R61, R21, R60, and R63 did not produce any formic acid from amino acid fermentation. Succinic acid was also detected as a fermentation product of some $\mathrm{HAB}$ isolates, but the concentration was always $\leq 6.6 \mathrm{mmol}^{-1}$.

To evaluate the ability of these isolates to ferment carbohydrates, bacteria were cultivated in medium containing pentose or hexoses as a source of carbon and energy. Most isolates (84\%) could ferment glucose $\left(2 \mathrm{~g} \mathrm{l}^{-1}\right)$, with the exception of C34, R21, R40, R50, and R51 (Table 3), while eight isolates could grow on xylose $\left(2 \mathrm{~g} \mathrm{l}^{-1}\right)$ (Table 3). Three isolates (R21, R40, and R50) that were unable to ferment any of the sugars tested in this study were isolated from animals that received casein supplementation. Isolates C51, C89, C114, C117, and R90 could ferment all the sugars tested, but only isolate R90 was obtained from a supplemented animal (Table 3).

Because urea supplementation is a common practice in tropical regions, we examined whether the amino acid-fermenting bacteria could also metabolize urea as a nitrogen source. Additionally, the proteolytic activity of these isolates was investigated to gain further insight into the range of substrates used by these groups of bacteria. All strains grew when cultured in basal medium containing $7.5 \mathrm{~g} \mathrm{l}^{-1}$ of trypticase and $2.0 \mathrm{~g} \mathrm{l}^{-1}$ of urea. However, very little ureolytic activity (mean: $3.61 \pm$ $3.49 \mu \mathrm{mol} \mathrm{NH} \mathrm{NH}_{3} \mathrm{mg}$ protein ${ }^{-1} \mathrm{~min}^{-1}$ ) was observed in washed cultures incubated with $50 \mathrm{mmol} \mathrm{l}^{-1}$ urea, suggesting that this is not a suitable substrate to sustain the growth of these isolates (Table 4). Only isolates C47, C117, and R107 had ureolytic activities $>10 \mu \mathrm{mol} \mathrm{NH}_{3}$ $\mathrm{mg}$ protein ${ }^{-1} \mathrm{~min}^{-1}$. Additionally, little growth was observed when the isolates were cultivated with casein as the sole source of carbon and energy, and a low proteolytic activity $\left(0.18-31.3 \mathrm{U} \mu \mathrm{g}_{\text {protein }}{ }^{-1}\right)$ was detected in these cultures (Table 4).

$\mathrm{HAB}$ species are generally sensitive to ionophores, and the addition of $1 \mu \mathrm{mol} \mathrm{l}^{-1}$ of lasalocid or monensin to the culture medium containing trypticase $\left(15 \mathrm{~g} \mathrm{l}^{-1}\right)$ drastically reduced $(>90 \%)$ bacterial growth and the consequent accumulation of ammonia (data not shown) of all isolates tested in this study.

The 16S rRNA genes of the $30 \mathrm{HAB}$ that were selected for characterization were sequenced and compared with known sequences in the GenBank sequence database and the Ribosomal Database Project. Similarity analysis indicated that identity to the closest match in GenBank varied from 73-99\%, while hierarchical taxa assignment based on Ribosomal Database Project search results returned hits similar to the GenBank at the species level. Because the sequence similarity was generally low, it was difficult to phylogenetically match isolates with previously reported bacterial species. However, sequence comparisons carried out against both databases indicated a predominance of bacteria from the order Clostridiales.

Figure 3 shows the consensus phylogenetic tree obtained by bootstrap analysis (number of times the replication occurred in the group) considering 5000 replicates, and many branches were supported by bootstrap values $>90 \%$. The strains were grouped into five major clades descending from common ancestors represented as clades 1-5 in Figure 3. Seven HAB strains were most closely related to Clostridium argentinense (16S rRNA sequence identity 96-99\%), a bacterium 
Table 2 Fermentation products $\left(\mathrm{mmol} \mathrm{I}^{-1}\right)$ of hyper-ammonia-producing bacterial isolates* obtained from Nellore steers

\begin{tabular}{|c|c|c|c|c|c|c|c|c|c|}
\hline $\begin{array}{l}\text { Concentration of fermentation } \\
\text { end-products }\end{array}$ & Isolate ID & $\begin{array}{l}\text { Total VFA } \\
\left(\mathrm{mmol} \mathrm{I}{ }^{-1 * *}\right)\end{array}$ & A & $P$ & B & (\%) & $F$ & $S$ & Iv \\
\hline \multirow[t]{12}{*}{ High } & $\mathrm{C} 48$ & $79.9 \pm 2.35 a$ & 47.8 & 8.1 & 7.8 & 5.3 & 4.37 & 4.8 & 21.5 \\
\hline & C51 & $76.6 \pm 1.74 a$ & 54.2 & 7.1 & 7.3 & 5.1 & 1.57 & 1.5 & 23.0 \\
\hline & $\mathrm{C} 33$ & $73.3 \pm 3.16 a$ & 55.4 & 7.9 & 5.8 & 5.9 & 2.37 & nd & 22.3 \\
\hline & R34 & $71.0 \pm 1.30 \mathrm{a}$ & 37.4 & 3.7 & 5.9 & 5.3 & 1.78 & 1.7 & 44.0 \\
\hline & $\mathrm{C} 11$ & $68.4 \pm 4.84 a$ & 69.1 & 11.8 & 6.2 & 7.2 & 1.32 & nd & 4.2 \\
\hline & R36 & $66.7 \pm 3.14 a$ & 50.3 & 11.3 & 5.1 & 5.1 & 1.48 & nd & 26.5 \\
\hline & C47 & $64.4 \pm 1.94 a$ & 49.2 & 8.4 & 7.7 & 5.8 & 1.95 & nd & 26.7 \\
\hline & C37 & $62.5 \pm 0.99 a$ & 65.9 & 13.9 & 6.8 & 6.5 & 1.69 & nd & 5.0 \\
\hline & R40 & $60.6 \pm 5.15 a$ & 37.8 & 10.2 & 5.5 & 4.0 & 9.48 & nd & 32.9 \\
\hline & R90 & $60.2 \pm 2.34 a$ & 64.9 & 9.7 & 5.4 & 9.7 & 3.63 & 1.5 & 4.9 \\
\hline & R15 & $59.6 \pm 2.90 a$ & 67.4 & 10.1 & 6.9 & 8.2 & 1.94 & 0.5 & 4.7 \\
\hline & R23 & $53.7 \pm 3.47 a$ & 61.8 & 12.0 & 8.3 & 9.5 & 5.14 & nd & 3.0 \\
\hline \multirow[t]{10}{*}{ Medium } & C89 & $49.2 \pm 1.69 b$ & 57.1 & 9.5 & 7.3 & 6.0 & 14.9 & 2.5 & 2.4 \\
\hline & C34 & $45.5 \pm 3.25 b$ & 63.3 & 14.6 & 7.2 & 7.2 & 3.00 & nd & 4.5 \\
\hline & $\mathrm{C} 122$ & $45.0 \pm 2.42 b$ & 57.9 & 10.4 & 7.3 & 5.6 & 13.44 & 2.9 & 2.2 \\
\hline & R50 & $44.2 \pm 2.09 b$ & 66.8 & 10.1 & 7.3 & 7.8 & 2.89 & nd & 4.9 \\
\hline & R61 & $44.0 \pm 3.20 \mathrm{~b}$ & 39.0 & 7.3 & 6.6 & 4.4 & nd & nd & 42.5 \\
\hline & C114 & $43.6 \pm 1.05 b$ & 51.4 & 10.4 & 6.5 & 7.8 & 21.72 & nd & 2.0 \\
\hline & C118 & $41.6 \pm 1.21 b$ & 55.7 & 10.1 & 7.4 & 7.9 & 12.63 & 3.2 & 2.6 \\
\hline & R51 & $39.0 \pm 3.43 b$ & 50.1 & 16.9 & 9.0 & 6.8 & 13.43 & 1.6 & 1.9 \\
\hline & C54 & $38.3 \pm 1.88 b$ & 51.5 & 16.5 & 8.8 & 8.3 & 12.86 & nd & 1.8 \\
\hline & C117 & $34.5 \pm 3.92 b$ & 49.4 & 15.0 & 2.6 & 13.6 & 8.69 & 6.3 & 4.1 \\
\hline \multirow[t]{8}{*}{ Low } & R21 & $30.6 \pm 6.17 \mathrm{c}$ & 71.5 & 9.0 & 8.7 & 5.9 & nd & nd & 4.7 \\
\hline & R60 & $30.3 \pm 2.56 c$ & 66.0 & 8.4 & 13.5 & 6.2 & nd & nd & 5.8 \\
\hline & R91 & $25.0 \pm 1.05 c$ & 20.2 & 10.2 & 3.5 & 56.2 & 8.02 & nd & 1.6 \\
\hline & R63 & $22.9 \pm 0.61 c$ & 64.7 & 11.6 & 10.3 & 7.3 & nd & nd & 5.9 \\
\hline & R107 & $21.5 \pm 2.11 \mathrm{c}$ & 58.8 & 15.4 & 3.6 & 13.5 & 6.59 & nd & 1.9 \\
\hline & C116 & $19.3 \pm 4.17 \mathrm{c}$ & 50.0 & 17.2 & nd & 15.4 & 10.61 & 6.6 & nd \\
\hline & R96 & $16.9 \pm 3.34 c$ & 52.2 & 17.3 & 4.5 & 11.6 & 11.13 & nd & 3.0 \\
\hline & R97 & $12.2 \pm 5.97 \mathrm{c}$ & 47.8 & 25.7 & nd & 7.3 & 19.05 & nd & nd \\
\hline
\end{tabular}

$\mathrm{A}=$ acetate; $\mathrm{P}=$ propionate; $\mathrm{B}=$ butyrate; $\mathrm{lb}=$ isobutyrate; $\mathrm{F}=$ formate; $\mathrm{S}=$ succinate; $\mathrm{IV}=$ isovalerate; nd = not detected.

Values are provided as the mean \pm standard deviation of the mean.

*The isolates were grown in anaerobic mineral medium supplemented with $15 \mathrm{~g} \mathrm{l}^{-1}$ trypticase for $24 \mathrm{~h}$ at $39^{\circ} \mathrm{C}$

${ }^{* *}$ Averages of total volatile fatty acids followed by different letters in the same column differ at $5 \%$ probability by the Scott-Knott test.

that is distinct from C. botulinum, C. subterminale, and C. hastiforme and has been isolated from soil and blood samples.

Clade 2 contained eight strains that shared a common ancestor with strains in clade 1 . However, hierarchical taxon assignment within this clade was difficult as sequence analysis indicated very low homology (83-91\%) between our query sequences and other $16 \mathrm{~S}$ rRNA sequences deposited in the databases (see Additional file 1:
Table S1). Five isolates that grouped in clade 3 (C37, R60, R21, R61 and R63) were also only distantly related to other species of Clostridium (sequence identity $\leq 89 \%$ ).

Eight $\mathrm{HAB}$ isolates assigned to clade 4 were more closely related to well-known ruminal HAB (Clostridium sticklandii SR, Clostridium aminophilum F, Peptostreptococcus anaerobius $\mathrm{C}$, and Eubacterium pyruvativorans I-6) that were phylogenetically grouped within Cluster XI of the Clostridiales. However, in contrast to previous 
Table 3 Utilization of different carbon sources by hyper-ammonia-producing bacterial isolates* obtained from Nellore steers

\begin{tabular}{|c|c|c|c|c|c|c|c|}
\hline Isolate ID** & Trypticase & Cellobiose & Glucose & Maltose & Xylose & Casein & Trypticase + urea \\
\hline C11 & +++ & - & ++ & + & - & - & + \\
\hline C33 & +++ & + & ++ & - & - & - & + \\
\hline C34 & +++ & + & - & - & + & - & + \\
\hline C37 & +++ & - & ++ & + & - & + & + \\
\hline C47 & +++ & - & + & - & - & - & ++ \\
\hline C48 & +++ & - & +++ & +++ & - & - & + \\
\hline C51 & +++ & + & +++ & +++ & + & ++ & ++ \\
\hline C54 & +++ & ++ & + & ++ & - & - & ++ \\
\hline C89 & +++ & + & ++ & ++ & + & + & ++ \\
\hline C114 & ++ & ++ & ++ & ++ & + & + & + \\
\hline C116 & ++ & - & + & + & - & - & ++ \\
\hline C117 & +++ & + & + & + & + & + & ++ \\
\hline C118 & +++ & ++ & + & + & - & - & ++ \\
\hline C122 & +++ & + & +++ & ++ & - & + & ++ \\
\hline R15 & +++ & - & +++ & ++ & + & + & ++ \\
\hline R21 & +++ & - & - & - & - & + & + \\
\hline R23 & +++ & - & + & - & - & + & ++ \\
\hline R34 & +++ & + & + & ++ & - & - & + \\
\hline R36 & +++ & - & ++ & - & + & + & + \\
\hline R40 & +++ & - & - & - & - & - & + \\
\hline R50 & +++ & - & - & - & - & - & + \\
\hline R51 & +++ & - & - & + & - & - & + \\
\hline R60 & ++ & + & + & - & - & + & ++ \\
\hline R61 & ++ & + & + & + & - & + & ++ \\
\hline R63 & ++ & + & + & + & - & + & ++ \\
\hline R90 & +++ & + & ++ & + & + & + & ++ \\
\hline R91 & +++ & - & + & + & - & + & + \\
\hline R96 & ++ & + & ++ & + & - & + & ++ \\
\hline R97 & +++ & - & + & - & - & - & + \\
\hline R107 & +++ & - & + & - & - & + & +++ \\
\hline
\end{tabular}

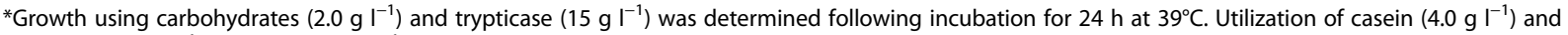
trypticase $\left(7.5 \mathrm{~g} \mathrm{l}^{-1}\right)$ plus urea $\left(2.0 \mathrm{~g} \mathrm{l}^{-1}\right)$ was determined following incubation of the isolates at $39^{\circ} \mathrm{C}$ for $48 \mathrm{~h}$.

${ }^{* *} \mathrm{C}$, isolates from animals not supplemented with casein; $\mathrm{R}$, isolates obtained from animals that received ruminal infusion of casein.

$(-)$ non-growth $\left(\mathrm{OD}_{600}<0.150\right) ;(+)$ change in $\mathrm{OD}_{600} 0.150-0.300 ;(++)$ change in $\mathrm{OD}_{600} 0.300-0.450 ;(+++) \mathrm{OD}_{600}>0.450$.

studies, all isolates within clade 4 could ferment carbohydrates as their sole source of carbon and energy. In particular, isolate R107 shared $99 \%$ identity with Clostridium bifermentans (Additional file 1: Table S1), a bacterium that shows arginine deaminase activity and can grow with Stickland pairs of amino acids. Isolates C34 and R36 were assigned to clade 5, containing species of Fusobacterium, and their closest match in Genbank was Fusobacterium varium, although with a very low sequence similarity ( $84 \%$ and $91 \%$ for C34 and R36, respectively) (Additional file 1: Table S1).

\section{Discussion}

In this work, RDP (casein) was supplemented into the rumen of Nellore steers, and changes in bacterial community composition were assessed to investigate the impact of supplementation on rumen ecology. PCR-DGGE and cluster analysis failed to discriminate the genetic diversity of the ruminal bacterial community in control (nonsupplemented) versus supplemented steers (Figure 1). Considering that species richness and population size are both components of diversity, the hypothesis that casein increases the number and/or metabolic activity of the 
Table 4 Proteolytic and ureolytic activities of hyperammonia-producing bacterial isolates* obtained from Nellore steers

\begin{tabular}{|c|c|c|c|}
\hline Isolate ID** & $\begin{array}{l}\text { Proteolytic } \\
\text { activity } \\
\text { in trypticase }^{1}\end{array}$ & $\begin{array}{l}\text { Proteolytic } \\
\text { activity } \\
\text { in Casein }{ }^{1}\end{array}$ & $\begin{array}{l}\text { Ureolytic } \\
\text { activity in } \\
\text { trypticase } \\
+ \text { urea }^{2}\end{array}$ \\
\hline C11 & $0.12 \pm 0.01$ & $0.86 \pm 0.06$ & $1.74 \pm 0.01$ \\
\hline C33 & $0.01 \pm 0.01$ & $1.18 \pm 0.04$ & $0.80 \pm 0.01$ \\
\hline C34 & $0.41 \pm 0.01$ & $10.87 \pm 0.08$ & $2.37 \pm 0.05$ \\
\hline C37 & $0.07 \pm 0.01$ & $0.40 \pm 0.03$ & $6.03 \pm 0.15$ \\
\hline C47 & $0.16 \pm 0.01$ & $0.89 \pm 0.08$ & $12.07 \pm 0.06$ \\
\hline C48 & $1.19 \pm 0.03$ & $4.30 \pm 0.16$ & $0.78 \pm 0.01$ \\
\hline C51 & $0.09 \pm 0.01$ & $0.18 \pm 0.01$ & $1.96 \pm 0.03$ \\
\hline C54 & $1.61 \pm 0.01$ & $5.17 \pm 0.26$ & $3.46 \pm 0.04$ \\
\hline C89 & $0.13 \pm 0.01$ & $2.52 \pm 0.02$ & $6.01 \pm 0.10$ \\
\hline C114 & $0.17 \pm 0.01$ & $0.66 \pm 0.01$ & $1.50 \pm 0.03$ \\
\hline C116 & $0.14 \pm 0.01$ & $0.83 \pm 0.07$ & $3.10 \pm 0.01$ \\
\hline C117 & $1.25 \pm 0.01$ & $31.26 \pm 1.76$ & $15.55 \pm 0.39$ \\
\hline C118 & $0.13 \pm 0.01$ & $0.91 \pm 0.01$ & $4.81 \pm 0.03$ \\
\hline C122 & $0.70 \pm 0.01$ & $1.36 \pm 0.09$ & $2.33 \pm 0.02$ \\
\hline R15 & $0.11 \pm 0.01$ & $0.38 \pm 0.01$ & $2.06 \pm 0.08$ \\
\hline R21 & $0.12 \pm 0.01$ & $0.81 \pm 0.04$ & $1.05 \pm 0.01$ \\
\hline R23 & $0.09 \pm 0.01$ & $4.02 \pm 0.16$ & $1.81 \pm 0.03$ \\
\hline R34 & $0.34 \pm 0.02$ & $0.91 \pm 0.08$ & $1.28 \pm 0.01$ \\
\hline R36 & $0.91 \pm 0.01$ & $1.55 \pm 0.09$ & $3.77 \pm 0.08$ \\
\hline R40 & $2.46 \pm 0.02$ & $9.48 \pm 0.37$ & $7.44 \pm 0.04$ \\
\hline R50 & $0.78 \pm 0.03$ & $1.65 \pm 0.17$ & $2.67 \pm 0.03$ \\
\hline R51 & $0.85 \pm 0.01$ & $0.87 \pm 0.04$ & $1.41 \pm 0.02$ \\
\hline R60 & $0.08 \pm 0.01$ & $0.61 \pm 0.06$ & $1.36 \pm 0.02$ \\
\hline R61 & $0.10 \pm 0.01$ & $0.42 \pm 0.04$ & $1.33 \pm 0.02$ \\
\hline R63 & $0.13 \pm 0.01$ & $0.46 \pm 0.07$ & $1.11 \pm 0.01$ \\
\hline R90 & $0.22 \pm 0.01$ & $0.79 \pm 0.07$ & $2.41 \pm 0.03$ \\
\hline R91 & $0.22 \pm 0.01$ & $1.38 \pm 0.38$ & $2.07 \pm 0.04$ \\
\hline R96 & $0.19 \pm 0.01$ & $0.68 \pm 0.09$ & $1.55 \pm 0.03$ \\
\hline R97 & $0.05 \pm 0.01$ & $1.17 \pm 0.13$ & $4.00 \pm 0.06$ \\
\hline R107 & $0.12 \pm 0.01$ & $0.99 \pm 0.31$ & $10.37 \pm 0.41$ \\
\hline
\end{tabular}

*Cultures were incubated for $48 \mathrm{~h}$ at $39^{\circ} \mathrm{C}$ in anaerobic mineral medium with limited nitrogen before the enzymatic activities were determined.

${ }^{* *} \mathrm{C}$, isolates from animals not supplemented with casein; $\mathrm{R}$, isolates obtained from animals that received ruminal infusion of casein.

${ }^{1} \mathrm{U} \mu \mathrm{g}$ protein ${ }^{-1}$.

${ }^{2} \mu \mathrm{mol} \mathrm{NH} \mathrm{Ng}_{3}$ protein ${ }^{-1} \mathrm{~min}^{-1}$.

Values are given as mean \pm standard deviation of the mean.

HABs, without affecting species richness, cannot be ruled out. This idea is supported by the observation that the rate of ammonia production increased approximately $33 \%$ in the rumen fluid of supplemented steers.

Previous studies using PCR-DGGE demonstrated that grouping of treatments by diet or rumen fraction (liquid or solid) is not always possible [22,23]. Additionally, individual variation between animals has frequently been demonstrated by DGGE profiling and other molecular techniques applied for microbial community analysis, indicating that the bacterial community composition may differ substantially even between animals fed the same diet [23-26].

To identify bacteria potentially involved in protein utilization and amino acid degradation in the rumen of the steers supplemented with casein, a series of enrichments and isolations were performed in medium containing a mixture of amino acids and peptides, aimed at selecting for specialized populations of anaerobic bacteria that contribute to the metabolism of dietary nitrogen in the rumen. Our enrichment and isolation strategy was based on previous observations that carbohydratefermenting ruminal bacteria have deamination rates of approximately $20 \mathrm{nmol} \mathrm{NH} \mathrm{mg}_{3}$ protein ${ }^{-1} \min ^{-1}[12,14]$, while the rates of ammonia production in obligate amino acid-fermenting bacteria are at least 10 -fold greater $[9,10,27]$.

In our study, isolates were selected as $\mathrm{HAB}$ if the specific activity of ammonia production was $\geq 100 \mathrm{nmol} \mathrm{NH_{3 }}$ mg protein ${ }^{-1} \mathrm{~min}^{-1}$, which has been previously reported for bacteria highly active in amino acid deamination [10,12-15]. A greater deamination activity was not always related to a higher concentration of ammonia in the growth medium, suggesting that these bacterial isolates differ in their ability to tolerate ammonia accumulation.

Amino acid fermentation yielded mainly acetic, propionic, butyric, isobutyric, and isovaleric acids (Table 2), which are produced from the oxidation of carbon skeletons derived from amino acid deamination [28]. Additionally, the proportion of fermentation products varied considerably among the isolates, with high levels of acetic, propionic, isovaleric, and isobutyric acids. Specifically, isolates R34 and R61 showed fermentation yields with $44.0 \%$ and $42.6 \%$ of isovaleric acid, respectively, a fermentation product mainly related to leucine utilization (Table 2) [9]. Isobutyric acid was the main fermentation end-product (56.2\%) of isolate R91, and production of this organic acid has been associated with valine fermentation [29].

Interestingly, three $\mathrm{HAB}$ isolates obtained in this work (R21, R40, and R50) only utilized amino acids as carbon and energy sources, a typical phenotype of the "classical HAB" $[9,10]$, but most of the isolates with high $\mathrm{NH}_{3}$ producing activity could also ferment carbohydrates (Table 3). Five of these isolates (C51, C89, C114, C117, and R90) could ferment hexoses, pentoses, and disaccharides. When Eschenlauer et al. [30] screened and characterized culturable HABs obtained from the rumen of fistulated sheep, 19 anaerobic bacteria showing high rates of ammonia formation in M2 medium were isolated. However, only the nonsaccharolytic isolates showed 


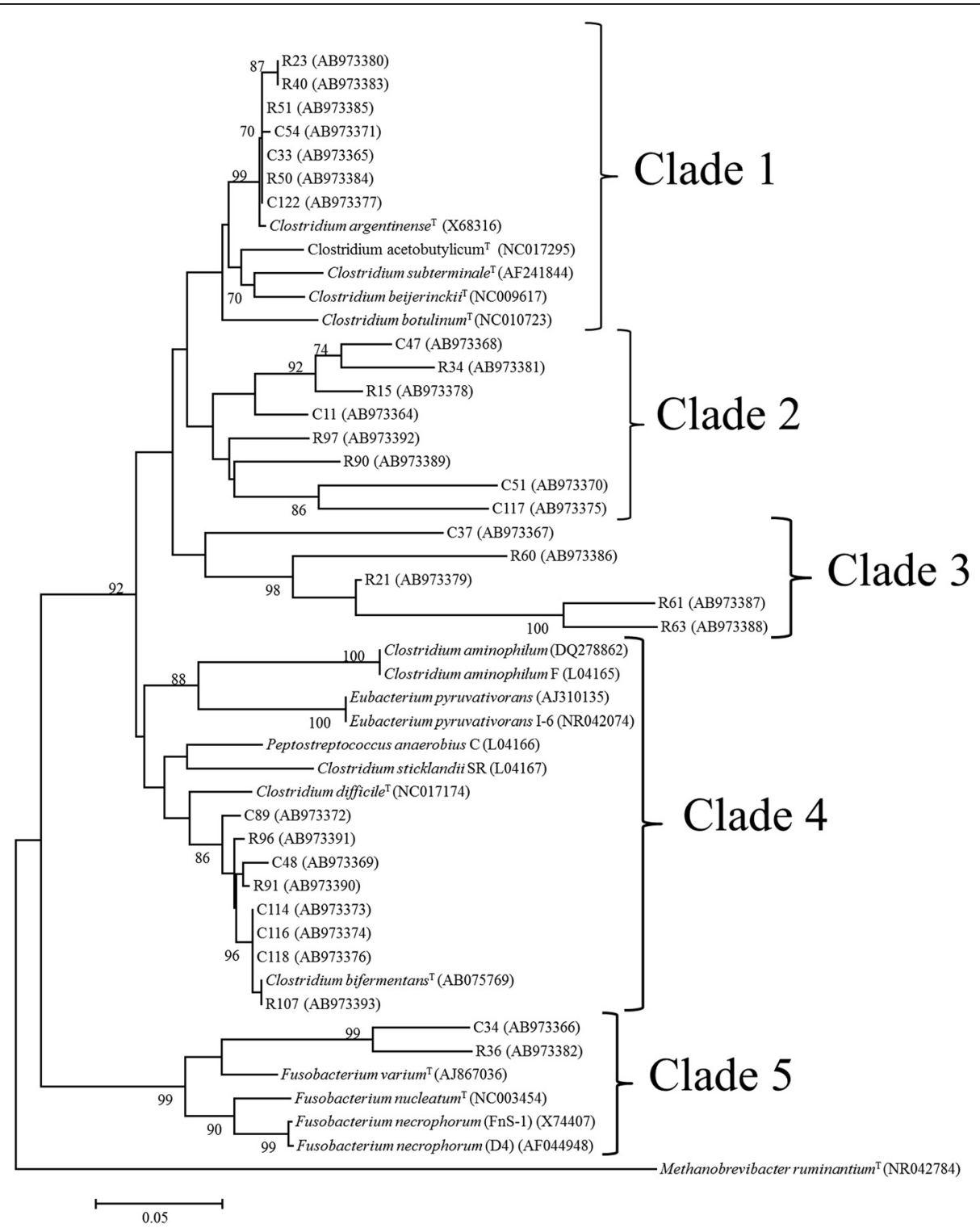

Figure 3 Phylogenetic relationships of the hyper-ammonia-producing bacteria (HAB) isolated from Nellore steers. The consensus tree, based on the neighbor-joining method, was constructed with 5000 repetitions using the program MEGA 4.0. Tree construction was based on $16 \mathrm{~S}$ rRNA sequences of the HAB isolates, and included known HAB and other bacteria. The GenBank accession numbers of the bacterial strains are indicated in parentheses. Only branches with bootstrap values $>70 \%$ are shown. The scale bar represents five nucleotide changes per 100 nucleotides analyzed.

deamination activity in medium containing trypticase as the sole source of carbon and energy. Additionally, Attwood et al. [12] previously found that HAB isolates obtained from the rumen of cattle, sheep, and deer could ferment different carbohydrates, including glucose, fructose, cellobiose, xylose, maltose, and trehalose, but the deamination rates of these isolates were not determined. A later work demonstrated that $F$. necrophorum, a ruminal $\mathrm{HAB}$, could utilize glucose, maltose, and galactose, but only if a source of amino acids and peptides (such as trypticase) or yeast extract was provided in the growth medium. If these other carbon sources were not present, no growth was observed [14].

Considering that carbohydrate-fermenting $\mathrm{HAB}$ and obligate amino acid-fermenting $\mathrm{HAB}$ obtained in this study deaminated at similar rates, which has not previously been reported for other $\mathrm{HAB}$, it appears that the former group might have a role in amino acid deamination not yet accounted for by previous studies. Previous estimates of the ruminal $\mathrm{HAB}$ population in the rumen varied from $<1 \%$ to $>17 \%$, but these studies mainly used enumeration in selective media containing amino acids 
as the sole source of carbon and energy, or were based on mathematical models that accounted for ammonia production by specific groups of ammonia-producing ruminal bacteria [31]. Previous enumeration studies using $16 \mathrm{~S}$ rRNA and protein profiling also indicated that populations of $\mathrm{HAB}$ accounted for $<2 \%$ of the total ruminal bacterial population [32]. Because carbohydrate-fermenting bacteria with high rates of ammonia production were overlooked in these previous studies, their role in amino acid degradation should be assessed to fully explain nitrogen transactions in the rumen. It should also be emphasized that, under our experimental conditions, only $12 \%$ of the 250 isolates obtained from enrichment cultures had rates of deamination $>100 \mathrm{nmol} \mathrm{NH}_{3}$ mg protein ${ }^{-1} \min ^{-1}$ (mean of $273.4 \mathrm{nmol} \mathrm{NH}_{3} \mathrm{mg}$ protein ${ }^{-1} \mathrm{~min}^{-1}$ ). Nonetheless, $90 \%$ of the isolates selected as HAB could also ferment carbohydrates in vitro, regardless of whether they were isolated in medium containing 1.5 or $15 \mathrm{~g} \mathrm{l}^{-1}$ trypticase or if they were obtained from animals with or without casein infusion into the rumen.

Most HABs isolated in this study were unable to use casein as a carbon source or grew poorly in the presence of this substrate (Table 3). Assessment of proteolytic activity showed that these isolates were not able to hydrolyze proteins to sustain growth. Similar results were observed when the isolates were grown with urea and the ureolytic activity was determined (Table 4). McSweeney et al. [19] reported a proteolytic activity of $105 \mathrm{U} \mathrm{OD}^{-1}$ for Prevotella ruminicola $\mathrm{B} 14$, while other ruminal bacteria had activities above $160 \mathrm{U} \mathrm{OD}^{-1}$. Selenomonas ruminantium growing in $0.3 \%$ urea produced $\geq 200 \mu \mathrm{mol} \mathrm{NH} \mathrm{NH}_{3} \mathrm{mg}$ protein ${ }^{-1} \mathrm{~min}^{-1}$ [33], and Dupuy et al. [34] reported a ureolytic activity of $>5.6 \mu \mathrm{mol} \mathrm{NH} \mathrm{NH}_{3} \mathrm{mg}$ protein ${ }^{-1} \mathrm{~min}^{-1}$ for Clostridium perfringens. Interestingly, until now, most species characterized as ruminal HAB showed little or no ureolytic activity [11-14]. In a previous work, Flythe and Andries [15] isolated HABs from Boer goats that were closely related to Peptoniphilus indolicus and had weak ureolytic activity $\left(<100 \mathrm{nmol} \mathrm{mg}\right.$ cell protein $\left.{ }^{-1} \mathrm{~min}^{-1}\right)$. Ureolytic bacteria could play an important role in ruminal nitrogen metabolism by recycling urea via saliva or the rumen wall, making the amino nitrogen available for the growth of rumen microbes [8,35].

Several bacterial species described as HAB (C. sticklandii SR, $P$. anaerobius $C$, and $F$. necrophorum) are sensitive to ionophores $[11,12,14,27]$. Ionophores modify the movement of ions through the cell membrane, altering proton gradients and energy transduction. In an attempt to maintain ion homeostasis, bacterial cells hydrolyze ATP, and this expenditure of energy may reduce biomass formation or cause loss of viability [27]. All bacteria obtained in this study were sensitive to the ionophores monensin and lasalocid, even isolates C34 and R36 that were characterized as Gram-negative. This observation is consistent with previous data from Russell [14], who reported that Fusobacterium could not grow when incubated with $5 \mu \mathrm{M}$ monensin. These results reinforce the idea that ruminal bacteria with high SAD are generally sensitive to ionophores and support previous observations that the presence of an outer membrane alone does not necessarily confer a high degree of ionophore resistance [36].

$16 \mathrm{~S}$ rRNA sequencing analysis indicated a predominance of members of the order Clostridiales among the bacteria isolated in this study. Many isolates were only distantly related to previously reported HABs or other known bacterial species (Figure 3), and the phenotypic and biochemical characterization of the isolates set them apart from other well-known HABs. Phylogenetic analysis separated these isolates into five clades, but phenotypic and genotypic diversity was observed within each group. Most isolates were Gram-positive, anaerobic, spore-forming bacteria that could grow on carbohydrates and peptides. Only isolates C34 and R36 (Figure 3, clade 5) were Gram-negative. These nonmotile rods could ferment amino acids, hexoses, and xylose, and showed low proteolytic activity. Some of these morphological and biochemical traits are consistent with those given for species of the genus Fusobacterium, but many other physiological characteristics are not shared with other species belonging to this genus.

These results expand our existing knowledge on the biochemical and genetic diversity of $\mathrm{HAB}$, and emphasize the role of carbohydrate-fermenting bacteria in ammonia production in the rumen. To our knowledge, this is the first description of HAB isolated from Bos indicus, and further studies should investigate the predominance of ruminal HABs across different diets and supplementation schemes.

\section{Conclusions}

Improving the utilization of dietary nitrogen in the rumen can have a major economic impact on ruminant nutrition. Several proposed models of rumen fermentation recognize that ruminal bacteria have different patterns of nitrogen utilization, and that HAB appear to account for a large fraction of the amino nitrogen that is converted to ammonia in the rumen, even though they are not highly abundant. Although most HAB have been described as obligate amino acid-fermenting bacteria, the isolates obtained from Nellore steers fed tropical forages in this study were also able to metabolize sugars as a carbon source, which is a competitive advantage for niche exploitation and colonization in the rumen. Additionally, the biochemical and genetic analysis of these isolates indicated several features that are distinct from previously described strains. Considering that HABs play a role in the rapid turnover of peptides and amino acids that enter the rumen, and that 
an optimal balance between protein degradation and microbial protein synthesis in cattle can increase milk production and reduce nitrogen excretion into the environment, strategies to target the HABs (e.g. ionophores, bacteriocins, essential oils) might have an amino acidsparing effect in the rumen.

\section{Methods}

Animals, diets, and treatments

A group of four crossbred Nellore steers fistulated in the rumen with an average initial weight of $280 \pm 10 \mathrm{~kg}$ were used in this study, in accordance with a protocol approved by the Universidade Federal de Viçosa Ethics and Animal Care and Use Committee. The animals were housed in individual stalls with water and minerals ad libitum. The experiment was conducted during four experimental periods, each with a duration of 29 days. Animals in different treatment groups in each experimental period were rotated to avoid residual effects of treatments. The animals were allowed to adapt to the diet for 14 days prior to sampling. The diet comprised Tifton 85 (Cynodon sp.) hay with an average crude protein content of $7.8-9.8 \%$, based on dry matter. Daily feeding occurred at 6:00 a.m. and 6:00 p.m., and ruminal supplementation with casein started on the sixth day of each experimental period.

Protein supplementation aimed to provide $55 \%$ of the calculated RDP requirements for the animals (equivalent to $230 \mathrm{~g}$ of casein per day per animal). Supplemented animals were infused with two portions of $115 \mathrm{~g}$ of pure casein (Labsynth, Diadema, Brazil) directly into the rumen at feeding. Control animals received a diet of basal forage only.

\section{Analysis of the bacterial community composition by PCR-DGGE}

To assess the genetic diversity of the ruminal microbial community, samples $(50 \mathrm{ml})$ of ruminal fluid were collected $6 \mathrm{~h}$ after daily feeding. The samples were stored at $-80^{\circ} \mathrm{C}$ and processed separately by treatment, time, and animal. For DNA extraction, the samples were defrosted at room temperature and processed according to the methods described by Stevenson and Weimer [37]. The first PCR reaction used the bacterial universal primers 9bfm (5'-GAGTTTGATYHTGGCTCAG-3') and 1512uR (5'-ACGGHTACCTTGTTACGACTT-3') to amplify the 16S rRNA genes from the genomic DNA of bacteria in rumen fluid samples [38]. The amplification reaction contained GoTaq Reaction Buffer (0.5 X), $\mathrm{MgCl}_{2}\left(0.5 \mathrm{mmol} \mathrm{l}^{-1}\right)$, dNTPs $\left(0.2 \mathrm{mmol} \mathrm{l}^{-1}\right)$, forward primer $\left(0.12 \mathrm{mmol} \mathrm{l}^{-1}\right)$, reverse primer $\left(0.12 \mathrm{mmol} \mathrm{l}^{-1}\right)$, Taq DNA polymerase $\left(0.1 \mathrm{u}^{-1} \mathrm{l}^{-1}\right)$ (Promega Corporation, Madison, WI, USA), BSA $\left(0.08 \mathrm{mg} \mathrm{ml}^{-1}\right)$ and genomic DNA $\left(0.8 \mathrm{ng}^{\mathrm{l}} \mathrm{l}^{-1}\right)$. The PCR was performed with an initial denaturation at $96^{\circ} \mathrm{C}$ for $4 \mathrm{~min}$, followed by 35 cycles of $96^{\circ} \mathrm{C}$ for $1 \mathrm{~min}, 56^{\circ} \mathrm{C}$ for $1 \mathrm{~min}$, and $72^{\circ} \mathrm{C}$ for $2 \mathrm{~min}$, followed by a final extension at $72^{\circ} \mathrm{C}$ for $5 \mathrm{~min}$ [38].

To increase the specificity of the analysis, nested-PCR was performed to amplify a shorter region (expected size of $177 \mathrm{bp}$ ) of the bacterial $16 \mathrm{~S}$ rRNA gene $[39,40]$ using the primers $341 \mathrm{f}-\mathrm{GC}$ ( 5 '-CCTACGGGAGGCAG CAGCGCCCGCCGCGCGCGGCGGGCGGGGCGGG GGCACGGGGGG-3') and 518r (5' -ATTACCGCGG CTGCTGG-3') [38]. The amplification reaction contained GoTaq Reaction Buffer (0.5 X), $\mathrm{MgCl}_{2}$ $\left(0.5 \mathrm{mmol} \mathrm{l}^{-1}\right)$, dNTPs $\left(0.2 \mathrm{mmol} \mathrm{l}^{-1}\right)$, forward primer $\left(0.12 \mathrm{mmol} \mathrm{l}^{-1}\right)$, reverse primer $\left(0.12 \mathrm{mmol} \mathrm{l}^{-1}\right)$, Taq DNA polymerase $\left(0.1 \mathrm{u} \mathrm{H}^{-1}\right)$ (Promega Corporation, Madison, WI, USA) and BSA $\left(0.08 \mathrm{mg} \mathrm{ml}^{-1}\right)$. One microliter of the amplification product from the first reaction was used as the DNA template. The nested-PCR was performed in a Biocycler MG96G thermocycler with an initial denaturation of $96^{\circ} \mathrm{C}$ for $4 \mathrm{~min}$, followed by 35 cycles of $96^{\circ} \mathrm{C}$ for $1 \mathrm{~min}, 56^{\circ} \mathrm{C}$ for $1 \mathrm{~min}$, and $72^{\circ} \mathrm{C}$ for $30 \mathrm{~s}$, followed by a final extension at $72^{\circ} \mathrm{C}$ for $5 \mathrm{~min}$ [38].

DGGE was performed in a DGGE-2401 apparatus (CBS Scientific Company, San Diego, CA, USA) using $8 \mu \mathrm{l}$ of the PCR products from the nested-PCR and $8 \mu \mathrm{l}$ of sample buffer $(0.05 \%$ bromophenol blue, $0.05 \%$ xylene cyanol, $70 \%$ glycerol and $1 \times$ TAE $\left(40 \mathrm{mmol} \mathrm{l}^{-1}\right.$ Tris, $20 \mathrm{mmol} \mathrm{l}^{-1}$ acetic acid, and $1 \mathrm{mmol} \mathrm{l}^{-1}$ EDTA)). The PCR products were loaded into wells in a $8 \%(\mathrm{w} / \mathrm{v})$ vertical polyacrylamide gel (acrylamide:N,N'-methylenebisacrylamide, 37.5:1) with a linear gradient of $40-60 \%$ urea/ formamide.

The denaturing gradient was obtained by mixing two solutions (A and B) dispensed by an MPP-100-220 peristaltic mini-pump (CBS Scientific Company, San Diego, CA, USA). Solution A contained $100 \%$ of the denaturing agents $\left(7 \mathrm{~mol} \mathrm{l}^{-1}\right.$ urea and $40 \%$ deionized formamide $\left.(\mathrm{v} / \mathrm{v})\right)$ in $8 \%$ acrylamide: N,N'-methylenebisacrylamide (37.5:1), and solution B was prepared as for solution A but without the denaturing agents. Solutions A and B also contained ammonium persulfate $\left(3.1 \mathrm{mmol} \mathrm{l}^{-1}\right)$ of polymerizer and $\mathrm{N}, \mathrm{N}$, $\mathrm{N}^{\prime}, \mathrm{N}^{\prime}$-tetramethylethylenediamine $\left(0.0037 \mathrm{mmol} \mathrm{l}^{-1}\right)$ catalyst. The denaturing gradient was monitored using $20 \mu \mathrm{l}$ of the visualization dye (bromophenol blue 0.5\%, xylene cyanol $0.5 \%$, and $1 \times \mathrm{TAE}$ ). The gels were allowed to polymerize for $3 \mathrm{~h}$ prior to loading the DNA samples.

A mixture of $16 \mathrm{~S}$ rRNA amplicons obtained from the genomic DNA of Escherichia coli ATCC 29214 ( $\gamma$-Proteobacteria), Salmonella enterica Typhimurium AT CC 14028 ( $\gamma$-Proteobacteria), Bacillus cereus ATCC 14579 (Firmicutes), and Lactococcus lactis ATCC 19435 (Firmicutes) were used as markers for bacterial species in wells located in the sides of the gel. Electrophoresis was performed at $60^{\circ} \mathrm{C}$ in $1 \times \mathrm{TAE}$ at constant voltage of $150 \mathrm{~V}$ for $10 \mathrm{~h}$. The gel was stained for 20 minutes with SYBR Gold (Invitrogen) according to 
manufacturer's recommendations. The gel was visualized and photo-documented using Eagle Eye (Stratagene). Gel bands were analyzed using Bionumerics 5.1 (Applied Maths, Kortrijk, Belgium). Dice's similarity coefficient $\left(D_{\mathrm{sc}}\right)$ was used to compare the data sets with an optimization of $1 \%$ and a tolerance of $1.5 \%$. Clustering was performed using the unweighted pair group method (UPGMA).

\section{Isolation of HAB}

Rumen fluid was sampled after a period of diet adaptation (14 days) and $3 \mathrm{~h}$ after the morning feeding. Rumen contents were obtained from control and supplemented animals, filtered through four layers of cheesecloth, and stored in stoppered Erlenmeyer flasks in insulated containers. Ruminal fluid was collected from the center of the flask and used for bacterial enrichment in mineral media. Enrichments of amino acid-fermenting bacteria were carried out at $39^{\circ} \mathrm{C}$ in batch or continuous cultures with anaerobic mineral (AM) medium limited in nitrogen. The AM medium contained (per liter): $292 \mathrm{mg}$ $\mathrm{K}_{2} \mathrm{HPO}_{4} ; 240 \mathrm{mg} \mathrm{KH} \mathrm{PO}_{4} ; 480 \mathrm{mg} \mathrm{Na} \mathrm{SO}_{4} ; 480 \mathrm{mg}$ $\mathrm{NaCl} ; 100 \mathrm{mg} \quad \mathrm{MgSO}_{4} \cdot 7 \mathrm{H}_{2} \mathrm{O} ; 64 \mathrm{mg} \quad \mathrm{CaCl}_{2} \cdot 2 \mathrm{H}_{2} \mathrm{O}$; $4000 \mathrm{mg} \mathrm{Na}_{2} \mathrm{CO}_{3} ; 600 \mathrm{mg}$ cysteine hydrochloride, with added vitamins and minerals [10]. Trypticase (1.5 $\mathrm{g} \mathrm{l}^{-1}$ or $15 \mathrm{~g} \mathrm{l}^{-1}$ ) was used as the only source of carbon and energy to sustain bacterial growth in batch or continuous cultures. The culture medium was prepared under a $\mathrm{CO}_{2}$ atmosphere free of oxygen, and the $\mathrm{pH}$ was adjusted to 6.5 with $\mathrm{NaOH}$.

The continuous culture was inoculated with $10 \%(\mathrm{v} / \mathrm{v})$ rumen fluid, using a dilution rate of $0.07 \mathrm{~h}^{-1}$. The optical density $(600 \mathrm{~nm})$ of the fermentation vessel was monitored to determine when the steady state was achieved. Enrichments using batch cultures were performed by daily transfers of $10 \%(\mathrm{v} / \mathrm{v})$ inoculum into fresh $\mathrm{AM}$ medium containing $1.5 \mathrm{~g} \mathrm{l}^{-1}$ or $15 \mathrm{~g} \mathrm{l}^{-1}$ trypticase. Ammonia production was monitored at the end of each transfer (24 h incubation) until it reached a plateau (six transfers) to determine when the microbial community had stabilized.

Samples $(2 \mathrm{ml})$ were collected from batch and continuous cultures and serial dilutions (10-fold increments) were performed. Aliquots $(10 \mu \mathrm{l})$ of the dilutions were then spread onto the surface of solid AM medium containing $1.5 \mathrm{~g} \mathrm{l}^{-1}$ or $15 \mathrm{~g} \mathrm{l}^{-1}$ trypticase, with or without supplementation with clarified rumen fluid (30\%) (a total of four different selective media). The plates were incubated at $39^{\circ} \mathrm{C}$ in an anaerobic chamber (Coy Laboratory Products, Gras Lake, MI, USA) for up to $72 \mathrm{~h}$.

Resultant colonies showing phenotypic and morphological differences were selected and transferred to fresh liquid media corresponding to the respective isolation media. The batch cultures were incubated overnight $\left(39^{\circ} \mathrm{C}\right)$ and were stored at $-20^{\circ} \mathrm{C}$ [41] for subsequent phenotypic and genotypic characterization. Phenotypic characterization was performed in AM medium containing $15 \mathrm{~g} \mathrm{l}^{-1}$ of trypticase. Aliquots $(1 \mathrm{ml})$ obtained from actively growing cultures were used to prepare slides for differentiating morphological characteristics (form, arrangement, sporulation, motility) and Gram staining.

\section{Determination of SAD and ammonia concentration}

Ammonia concentration was determined by the colorimetric method of Chaney and Marbach [42]. Absorbance was measured at $630 \mathrm{~nm}$ in a Spectronic 20D spectrophotometer (Thermo Fisher Scientific, Madison, WI, USA) and ammonium chloride $\left(\mathrm{NH}_{4} \mathrm{Cl}\right)$ was used as a standard. Total ammonia $\left(\mathrm{mmol} \mathrm{l}^{-1}\right)$ was expressed as the difference between ammonia concentration at the time of inoculation and that following $24 \mathrm{~h}$ of incubation. Specific deamination activity was calculated as the difference in ammonia concentration $\left(\mathrm{mmol} \mathrm{l}^{-1}\right)$ between time points 0 and $6 \mathrm{~h}$, divided by microbial protein concentration $\left(\mathrm{mg} \mathrm{l}^{-1}\right)$ and the incubation time (minutes). Microbial protein was determined according to Bradford [43], using lysozyme as the standard.

\section{Determination of organic acid production}

Organic acid production was determined by HPLC in a Dionex Ultimate 3000 dual detector HPLC apparatus (Dionex Corporation, Sunnyvale, CA, USA) coupled to a refractive index Shodex RI-101 maintained at $40^{\circ} \mathrm{C}$. A Phenomenex Rezex ROA ion exchange column (300x $7.8 \mathrm{~mm}$ ) was used (Phenomenex Inc. Torrance, CA, USA) and was maintained at $45^{\circ} \mathrm{C}$. The mobile phase contained $5 \mathrm{mmol} \mathrm{l}^{-1} \mathrm{H}_{2} \mathrm{SO}_{4}$ and $0.35 \mathrm{mmol} \mathrm{l}^{-1}$ sodium-free EDTA,

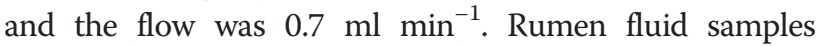
$(2.0 \mathrm{ml})$ were centrifuged $(12,000 \times g, 10 \mathrm{~min})$ and the cellfree supernatants were treated as described by Siegfried et al. [44].

The following organic acids were used to calibrate the standard curve: acetic, succinic, formic, propionic, valeric, isovaleric, isobutyric, and butyric acids. All acids were prepared to a final concentration of $10 \mathrm{mmol} \mathrm{l}^{-1}$, except isovaleric acid $\left(5 \mathrm{mmol} \mathrm{l}^{-1}\right)$ and acetic acid $\left(20 \mathrm{mmol} \mathrm{l}^{-1}\right)$.

\section{Substrate utilization and enzymatic activity}

To evaluate the ability of the bacterial strains to ferment carbohydrates, cultures were inoculated $(1 \%, \mathrm{v} / \mathrm{v})$ into basal medium containing (per liter): $0.292 \mathrm{~g} \mathrm{~K}_{2} \mathrm{HPO}_{4}$, $0.292 \mathrm{~g} \mathrm{KH}_{2} \mathrm{PO}_{4}, 0.48 \mathrm{~g}\left(\mathrm{NH}_{4}\right)_{2} \mathrm{SO}_{4}, 0.48 \mathrm{~g} \mathrm{NaCl}, 0.1 \mathrm{~g}$ $\mathrm{MgSO}_{4} .7 \mathrm{H}_{2} \mathrm{O}, 0.064 \mathrm{~g} \mathrm{CaCl}_{2} .2 \mathrm{H}_{2} \mathrm{O}, 0.5 \mathrm{~g}$ cysteine hydrochloride, $4 \mathrm{~g} \mathrm{Na}_{2} \mathrm{CO}_{3}, 0.1 \mathrm{~g}$ trypticase, and $0.5 \mathrm{~g}$ yeast extract. The following carbon sources were tested at $2 \mathrm{~g} \mathrm{l}^{-1}$ : glucose, cellobiose, maltose, and xylose. Growth was determined by measuring optical density at $600 \mathrm{~nm}$ 
in a Spectronic spectrophotometer 20D (Thermo Fisher Scientific, Madison, WI, USA) following $24 \mathrm{~h}$ of incubation. AM medium limited in nitrogen and supplemented with $15 \mathrm{~g} \mathrm{l}^{-1}$ of trypticase was used for comparison.

Proteolytic activity was determined in medium containing trypticase or casein. The strains were cultured in AM medium limited in nitrogen and supplemented with $15 \mathrm{~g} \mathrm{l}^{-1}$ trypticase or $4.0 \mathrm{~g} \mathrm{l}^{-1}$ casein. Samples $(2 \mathrm{ml})$ were collected after $48 \mathrm{~h}$ of incubation to determine proteolytic activity and microbial growth (OD $600 \mathrm{~nm}$ ). Assays for proteolytic activity were based on the method described by Forsythe [45], using 2\% (w/v) azocasein as a substrate. The proteolytic activity was expressed as activity units $(\mathrm{U})$ per $\mu \mathrm{g}$ protein $^{-1}$, in which a change of 0.01 absorbance units corresponded to $1 \mathrm{U}$ divided by the concentration $(\mu \mathrm{g})$ of microbial protein.

The urease activity was determined by culturing the strains in AM medium supplemented with $7.5 \mathrm{~g} \mathrm{l}^{-1}$ trypticase and $2.0 \mathrm{~g} \mathrm{l}^{-1}$ urea. Samples $(2 \mathrm{ml})$ were collected after 48 hours of incubation to determine the ureolytic activity and microbial protein concentration. The ureolytic activity assay followed the methods described by Cook [46]. The proteolytic activity was expressed as $\mu \mathrm{mol} \mathrm{NH} \mathrm{N}_{3}$ mg protein ${ }^{-1} \mathrm{~min}^{-1}$.

To determine the sensitivity of the bacterial isolates to ionophores, cultures were grown in AM medium limited in nitrogen and supplemented with $15 \mathrm{~g} \mathrm{l}^{-1}$ of trypticase. Monensin or lasalocid $\left(1 \mu \mathrm{mol} \mathrm{l}^{-1}\right)$ were added to the growth medium prior to inoculation. The OD at $600 \mathrm{~nm}$ was measured after $24 \mathrm{~h}$ of incubation and compared with control cultures without inhibitors.

\section{Phylogenetic analysis}

Taxonomic analysis of the bacterial strains used in this study was based on $16 \mathrm{~S}$ rRNA gene sequences. Approximately 50 ng of genomic DNA were used in the amplification reaction containing $5.0 \mu \mathrm{l}$ GoTaq Reaction Buffer (5x), $1.0 \mu \mathrm{l}$ dNTPs $\left(2.5 \mathrm{mmol} \mathrm{l}^{-1}\right), 1.0 \mu \mathrm{l}$ of each primer $\left(10 \mathrm{mmol} \mathrm{l}^{-1}\right), 0.2 \mu \mathrm{l} \mathrm{Taq}$ DNA polymerase (Promega), and $2.5 \mu \mathrm{l}$ of $\mathrm{MgCl}_{2}$. The universal primers 27F (5'AGAGTTTGATCMTGG-3') and 1392R (5' -ACGGGC GGTGTGTRC-3') were used for the amplification reaction. PCR was performed at $94^{\circ} \mathrm{C}$ for $3 \mathrm{~min}$ followed by 30 cycles of $94^{\circ} \mathrm{C}$ for $1 \mathrm{~min}, 50^{\circ} \mathrm{C}$ for $1 \mathrm{~min}$, and $72^{\circ} \mathrm{C}$ for $2 \mathrm{~min}$, with a final extension at $72^{\circ} \mathrm{C}$ for $7 \mathrm{~min}$. Products of each amplification reaction were analyzed by gel electrophoresis $(1.5 \%(\mathrm{w} / \mathrm{v})$ agarose).

The PCR products (expected size of $1365 \mathrm{bp}$ ) were purified and sequenced (Macrogen, Korea). The 16S rRNA sequence from each isolate was initially analyzed using the Basic Local Alignment Search Tool (BLAST). Sequences were compared with $16 \mathrm{~S}$ ribosomal RNA sequences of bacteria and archaea deposited in the GenBank sequence database and the Ribosomal Database
Project. ClustalW [47] alignments and manual gap corrections were made using the software MEGA 4.0 [48]. Phylogenetic inferences were obtained using MEGA 4.0, and the neighbor-joining method was used for tree construction [48].

\section{Nucleotide sequence accession numbers}

The 16S rRNA gene sequences of the bacterial isolates used in this study have been deposited in the DDBJ/ EMBL/GenBank databases under the accession numbers from AB973364 to AB973393. These sequences were used to construct the phylogenetic tree as well as other $16 \mathrm{~S}$ rRNA sequences obtained in the GenBank database for the following bacterial species (corresponding accession numbers are given in parenthesis): Clostridium argentinense (X68316), Clostridium acetobutylicum (NC017295), Clostridium subterminale (AF241844) Clostridium beijerinckii (NC009617), Clostridium botulinum ${ }^{\mathrm{T}}$ (NC010723), Clostridium aminophilum (DQ278862), Clostridium aminophilum F (L04165), Eubacterium pyruvativorans (AJ310135), Eubacterium pyruvativorans I-6 (NR042074), Peptostreptococcus anaerobius C (L04166), Clostridium sticklandii SR (L04167), Clostridium difficile ${ }^{\mathrm{T}}$ (NC017174), Clostridium bifermentans $^{\mathrm{T}}$ (AB075769), Fusobacterium varium ${ }^{T}$ (AJ867 036), Fusobacterium nucleatum ${ }^{\mathrm{T}}$ (NC003454), Fusobacterium necrophorum (FnS-1) (X74407), Fusobacterium necrophorum (D4) (AF044948) and Methanobrevibacter ruminantium $^{\mathrm{T}}$ (NR042784).

\section{Additional file}

Additional file 1: Table S1. Sequence similarity searching results for comparison of the $16 \mathrm{~S}$ ribosomal RNA sequences from hyper-ammoniaproducing bacterial isolates obtained from Nellore steers with the 16S rRNA sequences of Bacteria and Archaea in the GenBank sequence database. Only the match sequences with best scores for each individual isolate are listed.

\section{Abbreviations}

AM: Anaerobic mineral media; CP: Crude protein; DGGE: Denaturing gradient gel electrophoresis; NCBI: National Center for Biotechnology Information; HAB: Hyper-ammonia-producing bacteria; HPLC: High performance liquid chromatography; OD: Optical density; PCR: Polymerase chain reaction; RDP: Rumen-degradable protein; SAD: Specific activity of deamination.

\section{Competing interests}

The authors declare that they have no competing interests.

\section{Authors' contributions}

All authors designed experiments, interpreted data, and prepared the manuscript. ED performed animal adaptation, protein supplementation, and sampling of the animals. CBPB isolated the HAB and identified the culturable bacteria. ACA and CBPB performed the DGGE analysis. CBPB and HCM wrote the manuscript. All authors read and approved the final version of the manuscript.

\section{Acknowledgements}

This research was supported by the Conselho Nacional de Desenvolvimento Científico e Tecnológico (CNPq, Brasília, Brazil), the Coordenação de Aperfeiçoamento de Pessoal de Nível Superior (CAPES, Brasília, Brazil) and the Fundação de Amparo à Pesquisa do Estado de Minas Gerais (FAPEMIG, Belo 
Horizonte, Brazil). CBPB received a doctoral fellowship from the Fundação de Amparo à Pesquisa do Estado de Minas Gerais (FAPEMIG, Belo Horizonte, Brazil).

\section{Author details}

'Departamento de Microbiologia, Universidade Federal de Viçosa, Viçosa, MG 36570-000, Brazil. ²Departamento de Zootecnia, Universidade Federal de Viçosa, Viçosa, Minas Gerais, Brazil.

Received: 24 July 2014 Accepted: 2 February 2015

Published online: 14 February 2015

\section{References}

1. Costa VAC, Detmann E, Valadares Filho SC, Paulino MF, Henriques LT, Mantovani HC. Degradação in vitro da fibra em detergente neutro de forragem tropical de baixa qualidade em função de suplementação com proteína e/ou carboidratos. Rev Bras Zootecn. 2008;37(3):494-503.

2. Costa VAC, Detmann E, Valadares Filho SC, Paulino MF, Henriques LT, Mantovani HC. Degradação in vitro da fibra em detergente neutro de forragem tropical de alta qualidade em função da suplementação com proteína e/ou carboidratos. Rev Bras Zootecn. 2009;38(9):1803-11.

3. Costa VAC, Detmann E, Paulino MF, Valadares Filho SC, Carvalho IPC, Monteiro LP. Consumo e digestibilidade em bovinos em pastejo durante o período das águas sob suplementação com fontes de compostos nitrogenados e de carboidratos. Rev Bras Zootecn. 2011;40:1788-98.

4. Poppi DP, McLennan SR. Protein and Energy Utilization by Ruminants at Pasture. J Anim Sci. 1995:73:278-90.

5. Moraes EHBK, Paulino MF, Zervoudakis JT, Detmann E, Valadares Filho SC, Valadares RFD, et al. Níveis de proteína em suplementos para novilhos mestiços em pastejo durante o período de transição seca/águas. Rev Bras Zootecn. 2006:35:2135-43.

6. Detmann E, Paulino MF, Mantovani HC, Valadares Filho SC, Sampaio CB, Souza MA, et al. Parameterization of ruminal fibre degradation in lowquality tropical forage using Michaelis-Menten kinetics. Livest Prod Sci. 2009;126:136-46.

7. Bach A, Calsamiglia S, Stern MD. Nitrogen Metabolism in the Rumen. J Dairy Sci. 2005;88(E. Suppl):E9-E21.

8. Stewart GS, Smith CP. Urea nitrogen salvage mechanisms and their relevance to ruminants, non-ruminants and man. Nutr Res Rev. 2005;18:49-62.

9. Chen G, Russell JB. Fermentation of Peptides and Amino Acids by a Monensin-Sensitive Ruminal Peptostreptococcus. Appl Environ Microbiol. 1988;54(11):2742-9.

10. Chen G, Russell JB. More monensin-sensitive, ammonia-producing bacteria from the rumen. Appl Environ Microbiol. 1989;55(5):1052-7.

11. Paster BJ, Russell JB, Yang CMJ, Chow JM, Woese CR, Tanner R. Phylogeny of the Ammonia-Producing Ruminal Bacteria Peptostreptococcus anaerobius, Clostridium sticklandii and Clostridium aminophilum sp. Nov Int J Syst Bacteriol. 1993:43(1):107-10.

12. Attwood GT, Klieve AV, Ouwerkerk D, Patel BKC. Ammonia-hyperproducing bacteria from New Zealand ruminants. Appl Environ Microbiol. 1998;64(5):1796-804.

13. Wallace RJ, McKain N, McEwan NR, Miyagawa E, Chaudhary LC, King TP, et al. Eubacterium pyruvativorans sp. nov., a novel non-saccharolytic anaerobe from the rumen that ferments pyruvate and amino acids, forms caproate and utilizes acetate and propionate. Int J Syst Evol Micr. 2003;53:965-70.

14. Russell JB. Enrichment of fusobacteria from the rumen that can utilize lysine as an energy source for growth. Anaerobe. 2005;11:177-84.

15. Flythe MD, Andries $\mathrm{K}$. The effects of monensin on amino acid catabolizing bacteria isolated from the Boer goat rumen. Small Ruminant Res. 2009;81(2-3):178-81.

16. Taghavi-Nezhad M, Alipour D, Flythe MD, Zamani P, Khodakaramian G. The effect of essential oils of Zataria multiflora and Mentha spicata on the in vitro rumen fermentation, and growth and deaminative activity of amino acid-fermenting bacteria isolated from Mehraban sheep. Animal Production Science. 2013;54(3):299-307.

17. Russell JB, Onodera R, Hino T. Ruminal protein fermentation. News perspectives on previous contradictions. In: Tsuda T, Sasaki Y, Kawashima R, editors. Physiological aspects of digestion and metabolism in ruminants. New York: Academic Press; 1991. p. 681-97.

18. Krause DO, Russell JB. How many ruminal bacteria are there? J Dairy Sci. 1996;79(8):1467-75.
19. McSweeney CS, Palmer B, Bunch R, Krause AO. Isolation and Characterization of Proteolytic Ruminal Bacteria from Sheep and Goats Fed the Tannin-Containing Shrub Legume Calliandra calothyrsus. Appl Environ Microbiol. 1999;65(7):3075-83.

20. Whitehead TR, Cotta MA. Isolation and Identification of Hyper-Ammonia Producing Bacteria from Swine Manure Storage Pits. Curr Microbiol. 2004;48:20-6.

21. Richardson AJ, McKain N, Wallace RJ. Ammonia production by human faecal bacteria, and the enumeration, isolation and characterization of bacteria capable of growth on peptides and amino acids. BMC Microbiol. 2013;13:6-14.

22. Petri RM, Schwaiger T, Penner GB, Beauchemin KA, Forster RJ, McKinnon J, et al. Characterization of the Core Rumen Microbiome in Cattle during Transition from Forage to Concentrate as Well as during and after an Acidotic Challenge. Plos One. 2013;8(12):e83424.

23. Petri RM, Forster RJ, Yang W, McKinnonand JJ, McAllister TA. Characterization of rumen bacterial diversity and fermentation parameters in concentrate fed cattle with and without forage. J Appl Microbiol. 2012;112:1152-62.

24. Weimer PJ, Stevenson DM, Mertens DR. Shifts in bacterial community composition in the rumen of lactating dairy cows under conditions of milk fat depression. J Dairy Sci. 2010;93:265-78.

25. Weimer PJ, Stevenson DM, Mantovani HC, Man SLC. Host specificity of the ruminal bacterial community in the dairy cow following near-total exchange of ruminal contents. J Dairy Sci. 2010;93:5902-12.

26. Welkie DG, Stevenson DM, Weimer PJ. ARISA analysis of ruminal bacterial community dynamics in lactating dairy cows during the feeding cycle. Anaerobe. 2010;16:94-100.

27. Russell JB, Strobel HJ. Effect of ionophores on ruminal fermentation. Appl Environ Microbiol. 1989;55(1):1-6.

28. Russell JB. Rumen Microbiology and its role in ruminant nutrition. Ithaca, NY: Cornell University; 2002.

29. Menahan LA, Schultz LH. Metabolism of leucine and valine within the rumen. J Dairy Sci. 1964;47(10):1080-5.

30. Eschenlauer SCP, McKain N, Walker ND, McEwan NR, Newbold CJ, Wallace RJ. Ammonia Production by Ruminal Microorganisms and Enumeration, Isolation, and Characterization of Bacteria Capable of Growth on Peptides and Amino Acids from the Sheep Rumen. Appl Environ Microbiol. 2002;68(10):4925-31.

31. Rychlik JL, Russell JB. Mathematical estimations of hyper-ammonia producing ruminal bacteria and evidence for bacterial antagonism that decreases ruminal ammonia production. FEMS Microbiol Ecol. 2000;32:121-8.

32. Krause DO, Russell JB. An rRNA Approach for Assessing the Role of Obligate Amino Acid-Fermenting Bacteria in Ruminal Amino Acid Deamination. Appl Environ Microbiol. 1996;62(3):815-21.

33. John A, Isaacson HR, Bryant MP. Isolation and Characteristics of a Ureolytic Strain of Selenomonas ruminantium. J Dairy Sci. 1974;57(9):1003-14.

34. Dupuy B, Daube G, Popoff MR, Cole AT. Clostridium perfringens Urease Genes Are Plasmid Borne. Infect Immun. 1997;65(6):2313-20.

35. Bailey EA, Titgemeyer EC, Olson KC, Brake DW, Jones ML, Anderson DE. Effects of supplemental energy and protein on forage digestion and urea kinetics in growing beef cattle. J Anim Sci. 2012;90(10):3492-504.

36. Callaway TR, Russell JB. Variations in the ability of ruminal Gram-negative Prevotella species to resist monensin. Curr Microbiol. 2000;40:185-90

37. Stevenson DM, Weimer PJ. Dominance of Prevotella and low abundance of classical ruminal bacterial species in the bovine rumen revealed by relative quantification real-time PCR. Appl Microbiol Biot. 2007;75:165-74.

38. Muhling M, Woolven-Allen J, Murrell JC, Joint I. Improved group-specific PCR primers for denaturing gradient gel electrophoresis analysis of the genetic diversity of complex microbial communities. ISME J. 2008;2(4):379-92.

39. Heuer $H$, Krsek M, Baker P, Smalla K, Wellington EMH. Analysis of actinomycete communities by specific amplification of genes encoding $16 \mathrm{~S}$ rRNA and gel-electrophoretic separation in denaturing gradients. Appl Environ Microbiol. 1997;63:3233-41.

40. Gomes NC, Heur H, Scholfed J, Costa R, Mendoça-Hangler L, Smalla K. Bacterial diversity of the rhizosphere of maize (Zea mays) grown in tropical soil studied by temperature gradient gel electrophoresis. Plant Soil. 2001;232:167-80

41. Teather RM. Maintenance of Laboratory Strains of Obligately Anaerobic Rumen Bacteria. Appl Environ Microbiol. 1982;44(2):499-501.

42. Chaney AL, Marbach EP. Modified reagents for determination of urea and ammonia. Clin Chem. 1962:8:130-2. 
43. Bradford MM. A rapid and sensitive method for the quantification of microgram quantities of protein utilizing the principle of protein-dye binding. Anal Biochem. 1976;72:248-54.

44. Siegfried R, Ruckemann $H$, Stumpf $G$. Method for the determination of organic acids in silage by high performance liquid chromatography. Landwirt Forsch. 1984:37(3-4):298-304.

45. Forsythe SJ. Methods for Biochemical Studies. In: Levett PN, editor. Anaerobic Microbiology a practical approach. Oxford: Oxford University Press; 1991. p. 121-43.

46. Cook AR. Urease Activity in the Rumen of Sheep and the Isolation of Ureolytic Bacteria. J Gen Microbiol. 1976;9:32-48.

47. Tompson JD, Higgins DG, Gibsons TJ. CLUSTAL W: improving the sensitivity of progressive multiple sequence alignment through sequence weighting position-specific gap penalties and weight matrix choice. Nucleic Acids Res. 1994;22(22):4673-80.

48. Tamura K, Dudley J, Nei M, Kumar S. MEGA 4: Molecular Evolutionary Genetics Analysis (MEGA) Software Version 4.0. Mol Biol Evol. 2007;24:1596-9.

\section{Submit your next manuscript to BioMed Central and take full advantage of:}

- Convenient online submission

- Thorough peer review

- No space constraints or color figure charges

- Immediate publication on acceptance

- Inclusion in PubMed, CAS, Scopus and Google Scholar

- Research which is freely available for redistribution 